\title{
Ro52 autoantibodies arise from self-reactive progenitors in a mother of a child with neonatal lupus
}

\author{
Joanne H. Reed ${ }^{1}$, Miroslaw K. Gorny ${ }^{3}$, Liuzhe $\mathrm{Li}^{3}$, Timothy Cardozo ${ }^{4}$, Jill P. Buyon ${ }^{2}$, and \\ Robert M. Clancy ${ }^{2}$ \\ ${ }^{1}$ Dept. Immunology, Garvan Institute of Medical Research, Sydney, Australia \\ 2Dept. Medicine, Division of Rheumatology, New York University School of Medicine, New York, \\ USA \\ ${ }^{3}$ Dept. Pathology, New York University School of Medicine, New York, USA \\ ${ }^{4}$ Dept. Pharmacology, New York University School of Medicine, New York, USA
}

\section{Abstract}

The detection of cardiac conduction defects in an 18-24 week old foetus in the absence of structural abnormalities predicts with near certainty the presence of autoantibodies against $60 \mathrm{kD}$ and 52kD SSA/Ro in the mother regardless of her health status. Previous studies have emphasized these autoantibodies as key mediators of tissue injury. The aim of this study was to focus on the anti-Ro52 response to determine whether these autoantibodies originate from progenitors that are inherently self-reactive or from B-cells that acquire self-reactivity during an immune response.

We traced the evolution of two anti-Ro52 autoantibodies isolated from circulating IgG1-switched B-cells from an asymptomatic mother of a child with third degree congenital heart block. The autoantibodies were expressed as their immune form and as pre-immune ancestors by reverting somatic mutations to germline sequence. The reactivity of pre-immune and immune antibodies for Ro52, Ro60, La and DNA was measured. Both anti-Ro52 autoantibodies exhibited a low frequency of somatic mutations (3-4\%) and utilised the same heavy and light chain genes but represented distinct clones based on differing complementarity determining region sequences. Preand post-immune antibodies showed specific binding to Ro52 with no measurable reactivity for other autoantigens. Ro52 binding was higher for immune antibodies compared to pre-immune counterparts demonstrating that autoreactivity was enhanced by affinity maturation. These data indicate that Ro52 reactivity is an intrinsic property of the germline antibody repertoire in a mother with a pathogenic antibody defined by cardiac injury in her offspring, and implies defects in both central and peripheral tolerance mechanisms.

Publisher's Disclaimer: This is a PDF file of an unedited manuscript that has been accepted for publication. As a service to our customers we are providing this early version of the manuscript. The manuscript will undergo copyediting, typesetting, and review of the resulting proof before it is published in its final citable form. Please note that during the production process errors may be discovered which could affect the content, and all legal disclaimers that apply to the journal pertain. 


\section{INTRODUCTION}

The cardiac disease of neonatal lupus (cardiac NL) is a passively acquired autoimmune syndrome in which normally developing foetuses suffer irreversible damage to their hearts upon transplacental passage of maternal IgG autoantibodies (autoAbs). Cardiac conduction defects (most characteristic being congenital heart block) detected before or at birth, in the absence of structural abnormalities, almost universally predicts the presence of autoAbs against $60 \mathrm{kD}$ and 52kD SSA/Ro (Ro60 and Ro52) in the mother regardless of her health status [1]. Two hypotheses have emerged to explain the pathogenesis of cardiac NL, both of which emphasize autoAbs as the central mediators of tissue injury in the foetal heart. The apoptosis hypothesis states that the intracellular SSA/Ro antigens translocate to the surface of cardiomyocytes undergoing apoptosis during physiologic remodelling and are bound by maternal autoAbs forming immune complexes that promote pro-inflammatory and profibrotic responses [2-5]. The second hypothesis proposes that autoAbs cross-react with myocyte surface proteins, specifically L-type calcium channels and cause dysregulation of calcium homeostasis [6-9]. While there has been extensive investigation into the pathogenesis of anti-SSA/Ro autoAbs in cardiac NL, few studies have addressed where these autoAbs derive. Elucidating the origin of an autoAb response is critical for understanding autoimmunity in the mother and for proposing targeted therapies.

Autoantibodies can arise from two potential sources: a B cell that was "born" self reactive such that it has assembled an Ig surface receptor with moderate affinity for self antigen in the bone marrow; or a B cell that has acquired self reactivity by chance through somatic hypermutation during an immune response. $\mathrm{B}$ cells bearing antibodies with the heavy chain variable segment $I G H V 4-34 * 01$ are an example of a B cell born self-reactive [10-13]. Despite binding a pathologically significant blood cell surface autoantigen, IGHV4-34 B cells avoid clonal deletion in the bone marrow and constitute 5-10\% of the circulating naïve B cell repertoire in healthy individuals. However, these cells display characteristics of anergy with down-regulated surface $\operatorname{IgM}$ and functional unresponsiveness [14]. More recently, IGHV4-34 B cells were shown to participate in immune responses to foreign antigens by acquiring mutations to remove binding to self-blood cells, demonstrating a clonal redemption mechanism for acquiring self-non-self discrimination by mutation away from self [15]. In contrast to clonal redemption, other studies have demonstrated somatic hypermutation as a means to acquiring self-reactivity to specific autoantigens including dsDNA in SLE [16, 17], type 1 interferons in AIRE deficiency [18], desmoglenin-3 in pemphigus [19] and GM-CSF in pulmonary alveolar proteinosis [20]. In each study the reversion of all antibody somatic hypermutations to their germline sequence resulted in no measurable interaction with the self-antigen. These findings implied that self-reactivity was acquired by chance during an immune response to an unrelated exogenous antigen. The goal of this study was to determine whether anti-SSA/Ro autoAbs derive from B cells that are intrinsically self-reactive or acquire autoreactivity. We isolated anti-Ro52 autoAbs from an asymptomatic mother whose offspring were affected by cardiac NL, and showed that antiRo52 autoAbs derive from nascent self-reactive naïve B cells that required little somatic mutation. These data demonstrate that Ro52 reactivity is an inherent property of the 
germline antibody repertoire in a mother with a pathogenic autoAb defined by cardiac injury in her offspring.

\section{MATERIALS AND METHODS}

\subsection{Patients}

Peripheral blood was obtained from two mothers enrolled in the Research Registry for Neonatal Lupus. Both mothers were positive for anti-Ro autoAbs as determined by the NYU Langone Medical Centre diagnostic immunology laboratory using the BioPlex ${ }^{\circledR} 2200$ System ANA Screen with MDSS (BioRad) and AccuDiag ${ }^{\text {TM }}$ SSA (Ro) enzyme linked immunosorbent assay (ELISA) kit (Immuno Diagnostics). Reactivity for Ro52, Ro60 and La was also evaluated by an "in-house" ELISA as described below (section 2.4). Each mother had at least one pregnancy where the offspring was affected by cardiac NL. Donors were selected based on severity of foetal symptoms, specifically having more than one child with cardiac disease or a pregnancy resulting in the death of the foetus. Studies were approved by the institutional review board.

\subsection{Production of human monoclonal antibodies against recombinant Ro52 proteins}

Two human IgG1 monoclonal antibodies (mAbs), L2-7 and L2-14, were developed as previously described with some modifications [21]. Briefly, peripheral blood mononuclear cells (PBMC) were transformed with Epstein-Barr virus (EBV) and cultured with a polyclonal B cell activator, $\mathrm{CpG}$ which enhances EBV infection and B cell transformation [22]. The culture supernatants were screened for binding activity to recombinant Ro52, native Ro60 and native La by ELISA (see 2.4). The reactive cells were fused with the heteromyeloma cell line SHM-D33 [23] and the resulting hybridoma cells that continued to make functional antibodies were cloned once at 10 cells per well and twice at 1 cell per well of 96-well plates to achieve monoclonality. The specificity of mAbs was confirmed by ELISA and by the absence of any reactivity with control antigens. The hybridoma cells were used to isolate mRNA using Micro-FastTrack 2.0 Kit (Invitrogen, NY, USA) to determine the nucleotide sequences as described [24, 25]. Briefly, 5' rapid amplification of cDNA ends (RACE) was applied for one-sided PCR to obtain full-length cDNA without introducing mutations in framework 1 region of the immunoglobulin gene. First strand cDNA was synthesized using gene specific primers and superscript II RNase H Reverse Transcriptase (Invitrogen). A homopolymeric tail is added to the 3 '-end of the cDNA using TdT and $\mathrm{dCTP}$, then abridged anchor primer and second gene specific primer were used to amplify immunoglobulin genes and the PCR products were cloned into TOPO TA cloning (Invitrogen) vector for sequencing at Macrogen, Rockville, MD.

\subsection{Sequence analysis of antibodies and reversion to germline}

Somatic mutations in the closest matching $\mathrm{V}, \mathrm{D}$, and $\mathrm{J}$ elements were manually annotated using the IMGT V-quest junction analysis tool [26, 27]. Each heavy and light chain cDNA sequence was synthesized as its mutated immune form or as a pre-immune ancestor where all somatic mutations were reverted to germline sequence. Pre-immune and post-immune IgG1 mAbs were expressed and purified as described [15]. 


\subsection{Ro52, Ro60 and La ELISA}

Full-length recombinant Ro52 and La was generated as described [28] and native bovine Ro60 and La were purchased from Arotec Diagnostics. ELISA was done as previously described with some modifications [29]. Antigens ( $3 \mu \mathrm{g} / \mathrm{ml}$ in PBS) were coated in microtitre plates overnight at $4{ }^{\circ} \mathrm{C}$. Non specific sites were blocked with $2 \%$ BSA in PBS for $1 \mathrm{hr}$ at room temperature. Cell culture supernatant, purified mAbs or serum, diluted in $1 \%$ BSA in PBS were added to wells for $1 \mathrm{~h}$ at room temperature.

\subsection{Assay for polyreactivity}

Polyreactivity was evaluated by ELISA as described previously using double stranded (ds) DNA and LPS [30]. Antibodies eiJB40 and mG053 served as positive and negative controls for polyreactivity, respectively $[15,31]$.

\section{RESULTS AND DISCUSSION}

\subsection{Isolation of Ro52-specific monoclonal antibodies}

To determine whether SSA/Ro reactivity is inborn or acquired, we endeavoured to isolate anti-SSA/Ro mAbs from 2 mothers of children with cardiac manifestations of NL (Table 1). Both mothers were positive for anti-Ro60 and anti-Ro52 autoAbs, patient 125 also had low titre anti-La autoAbs. Patient 836 was diagnosed with systemic lupus erythematosus (SLE) and Sjogren's syndrome (SS) while patient 125 had one time photosensitivity but was otherwise asymptomatic and found to have anti-Ro autoAbs only after the diagnosis of heart block in her foetus. Screening supernatants from patient PBMC-derived hybridomas revealed two IgG1 mAbs, L2-7 and L2-14, reactive with Ro52 (Table 2). Both mAbs were isolated from donor 125 . The absence of mAbs obtained from 836 may be due to differences in medication use. Patient 836 was taking hydroxychlorquine for her SLE/SS symptoms. Since hydroxychloroquine interferes with Toll-like receptor (TLR) signalling [32-34], it is possible that the use of CpG oligodeoxynucleotide (TLR9 activator) to enhance EBV infection was inhibited in this donor's B cells resulting in reduced transformation efficiency. Other factors, in addition to medication, may contribute to differences in isolating mAbs, as a previous study isolated anti-Ro52 mAbs from only 1 of 3 patients with SLE despite all patients being untreated and seropositive for Ro [17]. Larger cohort studies are required to address the effect of medication, disease activity and other factors on the location and number of autoreactive B cells.

\subsection{Characteristics of human anti-Ro52 monoclonal antibodies}

Ro52 reactive mAbs, L2-7 and L2-14 utilised the same variable (V) and joining (J) heavy and light chain gene segments, IGHV3-23*01 and IGHJ4*02 paired with IGLV1-44*01 and $I G L J 3^{*} 02$. However, these antibodies represent distinct clones based on differences in the heavy chain complementarity determining region (CDR) 3 with only $53 \%$ homology and different diversity (D) gene segments (IGHD2-15*01 for L2-7 and IGHD3-22*01 for L2-14). Comparison of the L2-7 and L2-14 antibodies to the IMGT database-derived germline sequences revealed a low frequency of somatic hypermutations (Table 2). Overall, $3.6 \%$ and $3.3 \%$ of the heavy chain variable region was mutated in L2-7 and L2-14 
respectively, which is lower than the average somatic mutation rate of $8 \%$ observed in switched memory B cells from 9 healthy individuals [35]. Previous studies sequencing IgG1 memory B cells from patients with SLE [17] and serum-derived autoAbs [36] have also reported IGHV3-23 usage for Ro52 autoAbs. The L2-7 antibody contained mutations in the heavy chain CDR2 region S57T and upstream of CDR3 V93L (IMGT numbering), which were previously reported in anti-Ro52 autoAbs from 4/8 and 7/8 patients with Sjogren's syndrome [36]. Given the commonality of these mutations across unrelated patients, it is likely that they contribute to increasing affinity to Ro52.

\subsection{Evaluating the influence of somatic hypermutation on Ro52 reactivity}

Given that several human autoAbs have been reported to arise from somatic hypermutation [17-20], we next investigated whether somatic hypermutation was required for Ro52 reactivity. Antibodies L2-7 and L2-14 were expressed in their immune (mutated) form and pre-immune state, produced by reverting all somatic hypermutations back to their predicted germline sequence (Figures 1A,B and 2A, B). An ELISA with Ro52 antigen was used to evaluate reactivity of the expressed immune antibodies and their reverted pre-immune ancestors. Both pre-immune L2-7 and L2-14 reacted with Ro52, although binding of preimmune L2-7 to Ro52 was significantly less than the mutated counterpart (mean OD across concentrations 0.25 vs. 1.59 , pre-immune vs. immune, respectively, $p=0.0004$ unpaired Ttest) (Figure 1C). Similarly, the pre-immune L2-14 antibody showed less binding to Ro52 compared to the mutated L2-14 antibody (0.71 vs. 1.55 , respectively, $\mathrm{p}=0.0371$ ) (Figure 2C). Germline reactivity and affinity maturation of both L2-7 and L2-14 was highly specific to Ro52, as polyreactivity to other antigens, Ro60, La, dsDNA and LPS, was not detected (Figure 1D, 2D).

Since L2-7 and L2-14 did not require somatic hypermutation to recognise their antigen, it is likely that these anti-Ro52 autoAbs derive from naïve or anergic B cells that have avoided clonal deletion in the bone marrow. Yet, both L2-7 and L2-14 underwent class switching and affinity maturation toward Ro52, suggesting that these self-reactive B cells thwart both central and peripheral tolerance mechanisms. There are other instances where self-reactive germline antibodies are maintained in the periphery, the likely reason is to ensure breadth of the antibody repertoire. For example, B cells bearing IGHV4-34 bind poly-Nacetyllactosamine carbohydrates on erythrocytes and B cells [10-12], but can contribute to an immune response by undergoing somatic hypermutation to remove self-reactivity [15]. In contrast, anti-Ro52 autoAbs show a low frequency of somatic hypermutation and do not mutate away from self. The low rate of somatic mutations is consistent with the possibility that L2-7 and L2-14 originate from a T cell independent extrafollicular plasmablast response [37]. However, the affinity maturation towards Ro52 observed for L2-7 and L2-14 compared to their pre-immune counterparts as well as the chronic, high affinity and high titre antiRo52 autoAbs observed in patients argues against a short-lived, low-affinity extrafollicular response.

It is not known whether it is Ro52 itself or a cross-reactive foreign antigen that drives the initial and ongoing autoimmune response in patients. Current models for the Ro52 autoimmune response propose an initial inflammatory episode, possibly caused by viral 
infection, which increases Ro52 expression due to its role as an E3 ubiquitin ligase. Ro52 regulates type I interferon and cytokine production via the ubiquitination and degradation of pro-inflammatory transcription factors IRF3, IRF5, IRF7 and IRF8. It is proposed that inflammation not only increases Ro52 expression but also promotes apoptosis, which exposes the intracellular Ro52 protein for autoAb production [38]. The current study provides important insights into the generation of Ro52 autoimmunity, showing that these autoAbs arise from Ro52-reactive progenitors. An intriguing hypothesis that derives from this work is that these progenitors mature and persist by evading central and peripheral immune tolerance pathways, although a limitation of this study is that anti-Ro52 autoAbs were isolated from one patient. Further studies are required to determine whether Ro52 reactive autoAbs are a component of the germline repertoire in healthy non-autoimmune donors that are removed by acquired tolerance pathways to prevent anti-Ro52 autoAbs or whether specific Ro52 reactivity is unique to the germline antibody repertoire in patients with clinically overt autoimmunity as well as otherwise asymptomatic or pauci symptomatic mothers with pathogenic autoAbs solely defined by cardiac NL in their offspring.

\section{Acknowledgments}

We thank Professor Christopher Goodnow for discussions about the manuscript; Ms. Barbara Volsky for technical assistance in the isolation of monoclonal antibodies and Ms. Jennifer Jackson for the preparation and purification of recombinant monoclonal antibodies.

This work was supported by an Arthritis Australia grant (J.H.R.); National Health and Medical Research Council (NHMRC) Early Career fellowship (595989, J.H.R.); U.S. National Institutes of Health (NIH) grants (AI112546, M.K.G and OD004631, T.C); NIH Merit Award (R37 AR042455, 3R37 AR042455-21S1, 3R37 AR042455-21S2, J.P.B.), and the Research Registry for Neonatal Lupus (N01-AR-4-2220, J.P.B.).

\section{References}

1. Buyon, JP., Friedman, DM. Neonatal Lupus, in Systemic Lupus Erythematosus. Lahita, RG., et al., editors. Academic Press; San Diego: 2011. p. 541-567.

2. Clancy RM, Neufing PJ, Zheng P, O’Mahony M, Nimmerjahn F, Gordon TP, Buyon JP. Impaired clearance of apoptotic cardiocytes is linked to anti-SSA/Ro and -SSB/La antibodies in the pathogenesis of congenital heart block. J Clin Invest. 2006; 116(9):2413-22. [PubMed: 16906225]

3. Alvarez D, Briassouli P, Clancy RM, Zavadil J, Reed JH, Abellar RG, Halushka M, Fox-Talbot K, Barrat FJ, Buyon JP. A novel role of endothelin-1 in linking TLR7-mediated inflammation to fibrosis in congenital heart block. J Biol Chem. 2011 Jun 5 (Epub).

4. Buyon JP, Clancy RM. Dying right to live longer: positing apoptosis as a link between maternal autoantibodies and congenital heart block. Lupus. 2008; 17:86-90. [PubMed: 18250129]

5. Reed JH, Sim S, Wolin SL, Clancy RM, Buyon JP. Ro60 requires Y3 RNA for cell surface exposure and inflammation associated with cardiac manifestations of neonatal lupus. J Immunol. 2013; 191(1):110-6. [PubMed: 23698747]

6. Boutjdir M, Chen L, Zhang ZH, Tseng CE, DiDonato F, Rashbaum W, Morris A, el-Sherif N, Buyon JP. Arrhythmogenicity of IgG and anti-52-kD SSA/Ro affinity-purified antibodies from mothers of children with congenital heart block. Circ Res. 1997; 80(3):354-62. [PubMed: 9048655]

7. Boutjdir M, Chen L, Zhang ZH, Tseng CE, El-Sherif N, Buyon JP. Serum and immunoglobulin G from the mother of a child with congenital heart block induce conduction abnormalities and inhibit L-type calcium channels in a rat heart model. Pediatr Res. 1998; 44(1):11-9. [PubMed: 9667364]

8. Karnabi E, Qu Y, Wadgaonkar R, Mancarella S, Yue Y, Chahine M, Clancy RM, Buyon JP, Boutjdir M. Congenital heart block: identification of autoantibody binding site on the extracellular loop (domain I, S5-S6) of alpha(1D) L-type Ca channel. J Autoimmun. 2010; 34(2):80-6. [PubMed: 19640679] 
9. Ambrosi A, Dzikaite V, Park J, Strandberg L, Kuchroo VK, Herlenius E, Wahren-Herlenius M. Anti-Ro52 monoclonal antibodies specific for amino acid 200-239, but not other Ro52 epitopes, induce congenital heart block in a rat model. Ann Rheum Dis. 2012; 71(3):448-54. [PubMed: 22084395]

10. Childs RA, Dalchau R, Scudder P, Hounsell EF, Fabre JW, Feizi T. Evidence for the occurrence of O-glycosidically linked oligosaccharides of poly-N-acetyllactosamine type on the human leucocyte common antigen. Biochem Biophys Res Commun. 1983; 110(2):424-31. [PubMed: 6601483]

11. Pascual V, Victor K, Lelsz D, Spellerberg MB, Hamblin TJ, Thompson KM, Randen I, Natvig J, Capra JD, Stevenson FK. Nucleotide sequence analysis of the V regions of two IgM cold agglutinins. Evidence that the VH4-21 gene segment is responsible for the major cross-reactive idiotype. J Immunol. 1991; 146(12):4385-91. [PubMed: 1710250]

12. Silberstein LE, Jefferies LC, Goldman J, Friedman D, Moore JS, Nowell PC, Roelcke D, Pruzanski W, Roudier J, Silverman GJ. Variable region gene analysis of pathologic human autoantibodies to the related $i$ and I red blood cell antigens. Blood. 1991; 78(9):2372-86. [PubMed: 1657249]

13. Thompson KM, Sutherland J, Barden G, Melamed MD, Randen I, Natvig JB, Pascual V, Capra JD, Stevenson FK. Human monoclonal antibodies against blood group antigens preferentially express a VH4-21 variable region gene-associated epitope. Scand J Immunol. 1991; 34(4):509-18. [PubMed: 1718028]

14. Cappione A 3rd, Anolik JH, Pugh-Bernard A, Barnard J, Dutcher P, Silverman G, Sanz I. Germinal center exclusion of autoreactive B cells is defective in human systemic lupus erythematosus. J Clin Invest. 2005; 115(11):3205-16. [PubMed: 16211091]

15. Reed JH, Jackson J, Christ D, Goodnow CC. Clonal redemption of autoantibodies by somatic hypermutation away from self-reactivity during human immunization. J Exp Med. 2016; 213(7): 1255-65. [PubMed: 27298445]

16. Wellmann U, Letz M, Herrmann M, Angermuller S, Kalden JR, Winkler TH. The evolution of human anti-double-stranded DNA autoantibodies. Proc Natl Acad Sci U S A. 2005; 102(26):925863. [PubMed: 15968001]

17. Mietzner B, Tsuiji M, Scheid J, Velinzon K, Tiller T, Abraham K, Gonzalez JB, Pascual V, Stichweh D, Wardemann H, Nussenzweig MC. Autoreactive IgG memory antibodies in patients with systemic lupus erythematosus arise from nonreactive and polyreactive precursors. Proc Natl Acad Sci U S A. 2008; 105(28):9727-32. [PubMed: 18621685]

18. Meyer S, Woodward M, Hertel C, Vlaicu P, Haque Y, Karner J, Macagno A, Onuoha SC, Fishman D, Peterson H, Metskula K, Uibo R, Jantti K, Hokynar K, Wolff ASB, Krohn K, Ranki A, Peterson P, Kisand K, Hayday A, Collaborative AP. AIRE-Deficient Patients Harbor Unique High-Affinity Disease-Ameliorating Autoantibodies. Cell. 2016; 166(3):582-595. [PubMed: 27426947]

19. Di Zenzo G, Di Lullo G, Corti D, Calabresi V, Sinistro A, Vanzetta F, Didona B, Cianchini G, Hertl M, Eming R, Amagai M, Ohyama B, Hashimoto T, Sloostra J, Sallusto F, Zambruno G, Lanzavecchia A. Pemphigus autoantibodies generated through somatic mutations target the desmoglein-3 cis-interface. Journal of Clinical Investigation. 2012; 122(10):3781-3790. [PubMed: 22996451]

20. Piccoli L, Campo I, Fregni CS, Rodriguez BMF, Minola A, Sallusto F, Luisetti M, Corti D, Lanzavecchia A. Neutralization and clearance of GM-CSF by autoantibodies in pulmonary alveolar proteinosis. Nature Communications. 2015; 6

21. Gorny, MK. Production of human monoclonal antibodies via fusion of Epstein-Barr virustransformed lymphocytes with heteromyeloma, in Cell Biology: A laboratory handbook. C, JE., editor. Academic Press; 1994. p. 276-281.

22. Traggiai E, Becker S, Subbarao K, Kolesnikova L, Uematsu Y, Gismondo MR, Murphy BR, Rappuoli R, Lanzavecchia A. An efficient method to make human monoclonal antibodies from memory B cells: potent neutralization of SARS coronavirus. Nat Med. 2004; 10(8):871-5. [PubMed: 15247913]

23. Teng NN, Lam KS, Calvo Riera F, Kaplan HS. Construction and testing of mouse--human heteromyelomas for human monoclonal antibody production. Proc Natl Acad Sci U S A. 1983; 80(23):7308-12. [PubMed: 6316357] 
24. Gorny MK, Sampson J, Li H, Jiang X, Totrov M, Wang XH, Williams C, O’Neal T, Volsky B, Li L, Cardozo T, Nyambi P, Zolla-Pazner S, Kong XP. Human anti-V3 HIV-1 monoclonal antibodies encoded by the VH5-51/VL lambda genes define a conserved antigenic structure. PLoS One. 2011; 6(12):e27780. [PubMed: 22164215]

25. Li L, Wang XH, Banerjee S, Volsky B, Williams C, Virland D, Nadas A, Seaman MS, Chen X, Spearman P, Zolla-Pazner S, Gorny MK. Different pattern of immunoglobulin gene usage by HIV-1 compared to non-HIV-1 antibodies derived from the same infected subject. PLoS One. 2012; 7(6):e39534. [PubMed: 22761815]

26. Brochet X, Lefranc MP, Giudicelli V. IMGT/V-QUEST: the highly customized and integrated system for IG and TR standardized V-J and V-D-J sequence analysis. Nucleic Acids Res. 2008; 36(Web Server issue):W503-8. [PubMed: 18503082]

27. Giudicelli V, Brochet X, Lefranc MP. IMGT/V-QUEST: IMGT standardized analysis of the immunoglobulin (IG) and T cell receptor (TR) nucleotide sequences. Cold Spring Harb Protoc. 2011; 2011(6):695-715. [PubMed: 21632778]

28. Miranda-Carus ME, Boutjdir M, Tseng C-E, DiDonato F, Chan EK, Buyon JP. Induction of antibodies reactive with SSA/Ro-SSB/La and development of congenital heart block in a murine model. J Immunol. 1998; 161:5886-92. [PubMed: 9834068]

29. Reed JH, Clancy RM, Lee KH, Saxena A, Izmirly PM, Buyon JP. Umbilical cord blood levels of maternal antibodies reactive with p200 and full-length Ro 52 in the assessment of risk for cardiac manifestations of neonatal lupus. Arthritis Care Res (Hoboken). 2012; 64(9):1373-81. [PubMed: 22511615]

30. Tiller T, Meffre E, Yurasov S, Tsuiji M, Nussenzweig MC, Wardemann H. Efficient generation of monoclonal antibodies from single human B cells by single cell RT-PCR and expression vector cloning. J Immunol Methods. 2008; 329(1-2):112-24. [PubMed: 17996249]

31. Wardemann H, Yurasov S, Schaefer A, Young JW, Meffre E, Nussenzweig MC. Predominant autoantibody production by early human B cell precursors. Science. 2003; 301(5638):1374-7. [PubMed: 12920303]

32. Fox RI. Mechanism of action of hydroxychloroquine as an antirheumatic drug. Semin Arthritis Rheum. 1993; 23(2 Suppl 1):82-91. [PubMed: 8278823]

33. Sacre K, Criswell LA, McCune JM. Hydroxychloroquine is associated with impaired interferonalpha and tumor necrosis factor-alpha production by plasmacytoid dendritic cells in systemic lupus erythematosus. Arthritis Res Ther. 2012; 14(3):R155. [PubMed: 22734582]

34. Clancy RM, Markham AJ, Reed JH, Blumenberg M, Halushka MK, Buyon JP. Targeting downstream transcription factors and epigenetic modifications following Toll-like receptor 7/8 ligation to forestall tissue injury in anti-Ro60 associated heart block. J Autoimmun. 2016; 67:3645. [PubMed: 26432597]

35. Wu YC, Kipling D, Dunn-Walters DK. The relationship between CD27 negative and positive B cell populations in human peripheral blood. Front Immunol. 2011; 2:81. [PubMed: 22566870]

36. Arentz G, Thurgood LA, Lindop R, Chataway TK, Gordon TP. Secreted human Ro52 autoantibody proteomes express a restricted set of public clonotypes. J Autoimmun. 2012; 39(4):466-70. [PubMed: 22871259]

37. MacLennan IC, Toellner KM, Cunningham AF, Serre K, Sze DM, Zuniga E, Cook MC, Vinuesa CG. Extrafollicular antibody responses. Immunol Rev. 2003; 194:8-18. [PubMed: 12846803]

38. Oke V, Wahren-Herlenius M. The immunobiology of Ro52 (TRIM21) in autoimmunity: a critical review. J Autoimmun. 2012; 39(1-2):77-82. [PubMed: 22402340] 


\section{HIGHLIGHTS}

- Ro52 B cells were isolated from a mother of 2 children with autoimmune heart block

- Ro52 autoantibodies derive from self-reactive naïve B cells

- Ro52 autoantibodies undergo affinity maturation to enhance Ro52 binding 
A EVQLLESGGGLVQPGGSLRLSCAASGFTFSSYAMSWVRQAPGKGLEWVSAISGSGGSTYYAD

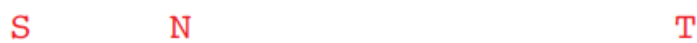

SVKGRFTISRDNSKNTLYLQMNSLRAEDTAVYYCAKVDIVVVVADYFDYWGQGTLVTVSS

L

I $\mathrm{E}$

B

QSVLTQPPSASGTPGQRVTISCSGSSSNIGSNTVNWYQQLPGTAPKLLIY SNNQRPSGVPDR

FSGSKSGTSASLAISGLQSEDEADYYCAAWDDSLNGWFVFGGGTKLTVLG

$\mathrm{E}$

C

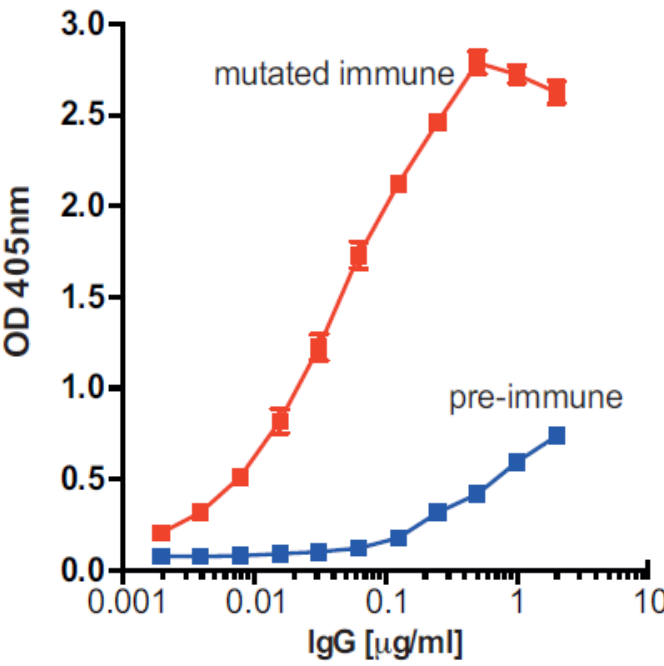

D

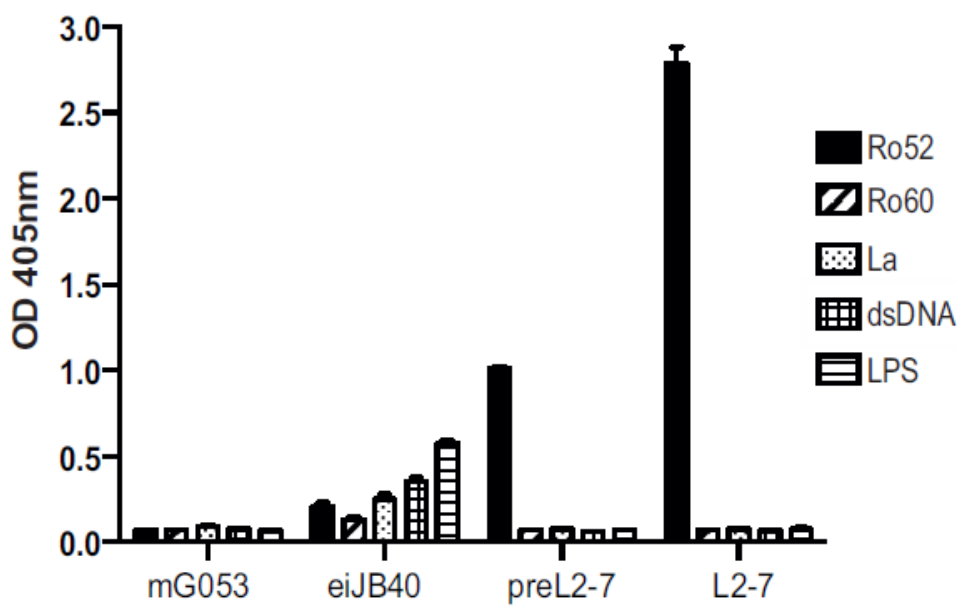

Figure 1.

Somatic hypermutation of L2-7 autoantibody increases specific reactivity to Ro52 autoantigen but does not acquire polyreactivity. (A and B) Variable domain amino acid sequence of the IMGT-predicted pre-immune 2-7 heavy chain (A) and light chain (B) and sequence substitutions acquired in the immune 2-7 antibody (shown below in red). Complementarity determining regions (CDR) underlined. (C) Binding of immune L2-7 and pre-immune L2-7 to recombinant Ro52 autoantigen by ELISA. Data are representative of two independent experiments with each data point showing the mean and standard deviation (SD) of triplicate determinations. (D) Binding of $\mathrm{L} 2-7 \mathrm{IgG}$, negative control mG053 and positive control eiJB40 ( $2 \mathrm{ug} / \mathrm{ml}$ ) to Ro52, Ro60, La, dsDNA and LPS by ELISA. Data points are the mean and SD of triplicates, representative of two independent experiments. 
A EVQLLESGGGLVQPGGSLRLSCAASGFTFSSYAMSWVRQAPGKGLEWVSAISGSGGSTYYAD $\mathrm{G}$ SVKGRFTISRDNSKNTLYLQMNSLRAEDTAVYYCAKHTMIVVDYYFDYWGQGTLVTVSS
$\mathrm{R}$
IH
S L
$\mathrm{S}$

$\mathrm{B}$ Q

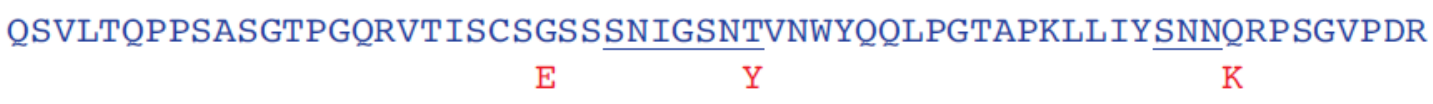

C
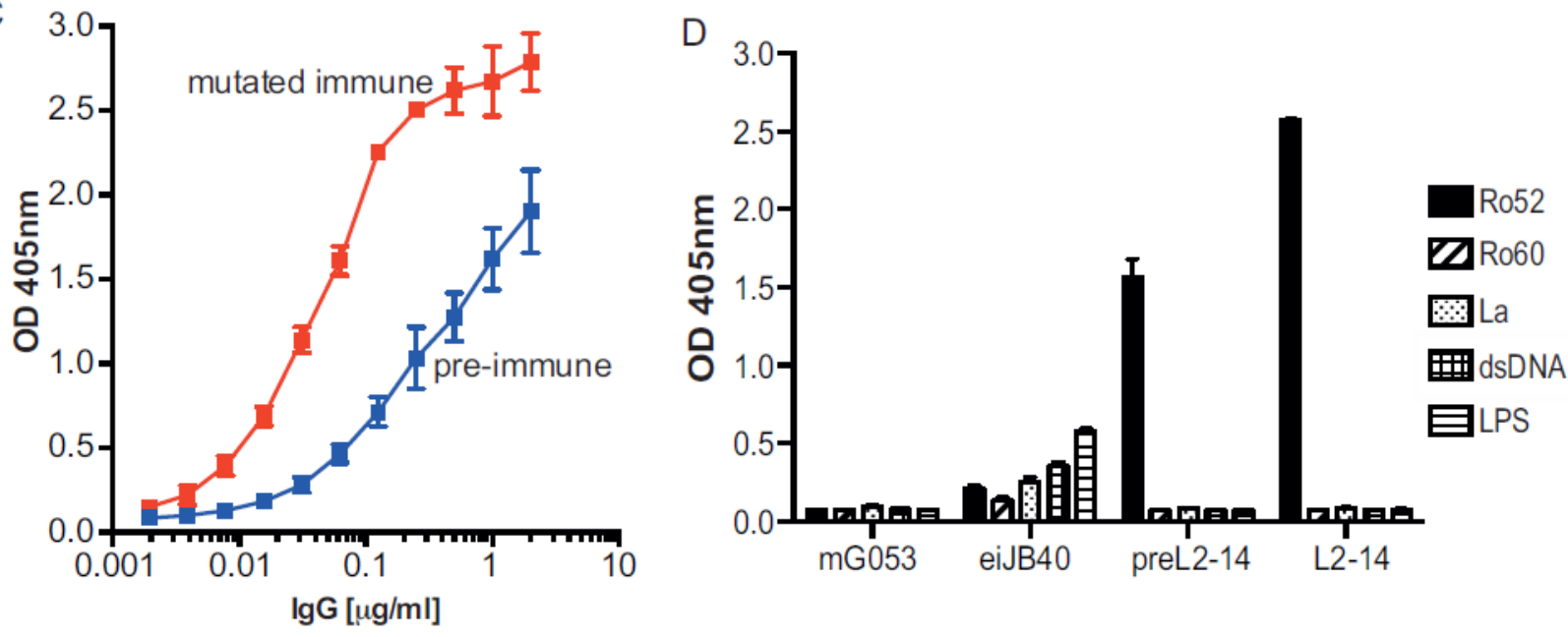

Figure 2.

The L2-14 antibody is highly reactive and specific for Ro52 in the mutated immune and germline pre-immune forms. (A and B) Variable region amino acid sequence of the preimmune L2-14 heavy chain (A) and light chain (B) and sequence substitutions acquired in the immune L2-14 antibody (shown below in red). CDRs underlined. (C) Binding of immune L2-14 and pre-immune L2-14 to recombinant Ro52 autoantigen by ELISA. Data are representative of two independent experiments with each data point showing the mean and SD of triplicate determinations. (D) Binding of L2-14 IgG1 and positive control IgG1 antibody, eiJB40 ( $2 \mathrm{ug} / \mathrm{ml})$ to LPS and dsDNA by ELISA. Data points are the mean and SD of triplicates, representative of two independent experiments. 


\section{Table 1}

Demographics of mothers providing peripheral blood for isolation of Ro52-specific monoclonal antibodies. CHB, congenital heart block; SLE, systemic lupus erythematosus; SS, Sjögren's syndrome.

\begin{tabular}{|l|l|l|}
\hline & Patient 836 & Patient 125 \\
\hline Pregnancy History & $1^{\text {st } \text { offspring - CHB, died in utero }}$ & $\begin{array}{l}1^{\text {st }} \text { offspring - CHB, transplant } \\
2^{\text {nd }} \text { offspring - healthy } \\
3^{\text {rd }} \text { offspring - transient 1 } 1^{\text {st }} \text { degree heart block }\end{array}$ \\
\hline Health Status & SLE/SS & Asymptomatic \\
\hline Medication & Hydroxychlorquine & None \\
\hline Serology & Anti-Ro52 + & Anti-Ro52 + \\
& Anti-Ro60 + & Anti-Ro60 + \\
& Anti-La - & Anti-La + (low titre) \\
\hline
\end{tabular}



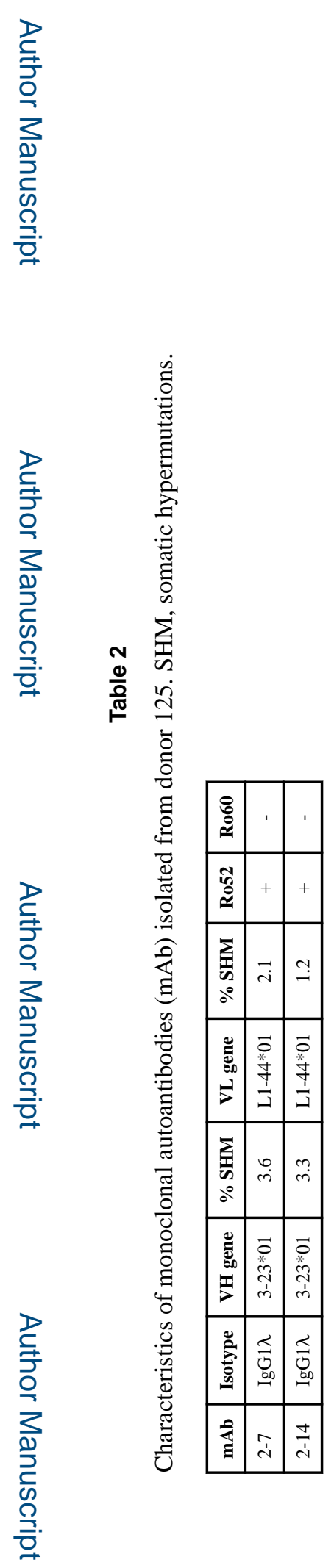